\title{
Analisis Hubungan Riwayat Keluarga dan Aktivitas Fisik dengan Kejadian Hipertensi di Kelurahan Indrasari Kabupaten Banjar
}

\author{
Elsi Setiandari L.O ${ }^{1}$, Ari Widyarni ${ }^{2}$, Aulia Azizah ${ }^{3}$ \\ ${ }^{1,2}$ Fakultas Kesehatan Masyarakat, Universitas Islam Kalimantan Muhammad Arsyad Al Banjari Banjarmasin \\ ${ }^{3}$ Fakultas Kedokteran Gigi, Universitas Lambung Mangkurat Banjarmasin \\ Correspondence email: setianoctavia86@gmail.com
}

\begin{abstract}
Abstrak. Hipertensi merupakan suatu keadaan dimana seseorang mengalami peningkatan tekanan darah diatas normal yang ditunjukkan oleh angka sistolik dan diastolik pada pemeriksaan tensi darah dengan menggunakan alat ukur tekanan darah. Angka kejadian hipertensi penduduk asia tenggara $24,7 \%$ dan $23,3 \%$ penduduk indonesia. hasil survei awal pengukuran tekanan darah serta wawancara diperoleh hasil pemeriksaan tekanan darah dari 30 warga masyarakat dengan kriteria tidak menderita hipertensi sebanyak 3 orang dan yang menderita pre-hipertensi sebanyak 9 orang dan yang menderita hipertensi sebanyak 18 orang. Tujuan Penelitian ini adalah untuk mengetahui analisis hubungan riwayat keluarga dan aktivitas fisik dengan kejadian hipertensi di Kelurahan Indrasari Kabupaten Banjar. Pada penelitian ini dilakukan dengan desain penelitian observasional analitik dan metode cross sectional. Populasi dalam penelitian ini adalah semua penderita hipertensi yang ada di kelurahan Indrasari yang memenuhi kriteria sebanyak 87 orang. Analisa data menggunakan analisis univariat menggunakan distribusi frekuensi dan analisis bivariat menggunakan uji chi-square. Hasil Penelitian dapat diketahui bahwa dari hasil uji chi square yaitu Ada hubungan antara riwayat keluarga, aktivitas fisik dengan kejadian hipertensi diperoleh nilai $p=0,001<\alpha 0,005$ dan diperoleh nilai $p=0,001<\alpha 0,005$. Berdasarkan hasil analisis penelitian dapat disimpulkan bahwa ada hubungan riwayat keluarga dan aktivitas fisik dengan kejadian hipertensi di Kelurahan Indrasari Kabupaten Banjar.
\end{abstract}

Kata kunci : Hipertensi; Riwayat Keluarga; Aktivitas Fisik

Abstract. Hypertension is a condition in which a person has an increase in blood pressure above normal as indicated by the systolic and diastolic numbers on blood pressure checks using a blood pressure measuring device. The incidence of hypertension in Southeast Asia is $24.7 \%$ and $23.3 \%$ of Indonesia's population. The results of the initial survey of blood pressure measurements and interviews obtained the results of blood pressure checks from 30 community members with the criteria not suffering from hypertension as many as 3 people and those suffering from pre-hypertension were 9 people and those suffering from hypertension were 18 people. The purpose of this study was to determine the analysis of the relationship between family history and physical activity with the incidence of hypertension in Indrasari Village, Banjar Regency. This research was conducted with an analytic observational research design and method cross sectional. The population in this study were all hypertension sufferers in Indrasari who met the criteria as many as 87 people. Data analysis used univariate analysis using frequency distribution and bivariate analysis using chi-square test. The results showed that from the results of the chi square test, there was correlation between family history, physical activity and the incidence of hypertension, the value was obtained $p=0.001<\alpha 0.005$ and the value obtained $p=0.001<\alpha 0.005$ was. Based on the results of the research analysis, it can be concluded that there is a relationship between family history and physical activity with the incidence of hypertension in Indrasari Village, Banjar Regency.

Keywords : Hypertension; Family History; Physical Activity

\section{PENDAHULUAN}

Terjadinya transisi epidemiologi, transisi demografi dan transisi teknologi di Indonesia telah mengakibatkan suatu perubahan pada pola penyakit, yaitu dari penyakit infeksi menjadi penyakit tidak menular (Rahajeng \& Sulistyo wati 2009). Prevalensi penyakit akibat gaya hidup yang tidak sehat di Indonesia semakin meningkat dari tahun ke tahun. Angka morbiditas pada penyakit tidak menular juga semakin tinggi. Hipertensi merupakan penyakit kardiovaskular yang berkontribusi untuk setidaknya $45 \%$ kematian akibat penyakit jantung, dan $51 \%$ dari kematian akibat stroke (Day, 2013). Menurut WHO yang dikutip oleh Rahajeng (2009) memperkirakan bahwa pada tahun 2020 penyakit tidak menular akan menyebabkan $73 \%$ kematian dan $60 \%$ kesakitan di dunia, dan diperkirakan negara yang paling merasakan dampaknya adalah negara berkembang termasuk Indonesia.

Penyakit hipertensi adalah peningkatan tekanan darah sistolik dari $140 \mathrm{mmHg}$ dan diastolik lebih dari 90 mmHg pada dua kali pengukuran dengan selang waktu lima menit dalam keadaan cukup istirahat/tenang (Robbins 2010). Penyakit tekanan darah tinggi atau hipertensi merupakan suatu keadaan dimana seseorang mengalami peningkatan tekanan darah diatas normal yang ditunjukkan oleh angka sistolik (bagian atas) dan diastolik (angka bawah) pada pemeriksaan tensi darah dengan menggunakan alat ukur tekanan darah, keadaan peningkatan tekanan darah ini dapat menimbulkan berbagai komplikasi seperti stroke, gagal ginjal, dan hipertrofi ventrikel kanan (Pudiastuti, 2011).

Penyakit hipertensi sering juga disebut sebagai the silent killer disease (Hartono, 2011) Penderita tidak 
mengetahui dirinya mengidap hipertensi sebelum memeriksakan tekanan darahnya. Penyakit ini dikenal juga sebagai heterogeneous group of disease karena dapat menyerang semua kelompok umur (Divine, 2012).

Meningkatnya prevalensi hipertensi pada umumnya disebabkan karena adanya perubahan gaya hidup, sehingga menyebabkan terjadinya pergeseran pola penyakit dari penyakit-penyakit infeksi bergeser ke penyakit-penyakit chronic degeneratif. Prevalensi hipertensi dari data statistik terbaru (WHO, 2013) Menyatakan bahwa terdapat $24,7 \%$ penduduk asia tenggara dan $23,3 \%$ penduduk indonesia dan di seluruh dunia berkisar satu milyar orang yang menderita hipertensi dan dua pertiga diantaranya berada di negara berkembang yang berpenghasilan rendah sampai sedang.

American Heart Association menyatakan penduduk Amerika yang berusia diatas 20 tahun yang menderita hipertensi telah mencapai 74,5 juta jiwa, dan hampir 90-95\% kasus tidak diketahui penyebabnya (Kemenkes RI, 2013). Secara umum, hipertensi dapat dicegah dengan menghindari faktor risiko yang dapat diubah yaitu merokok, mengkonsumsi garam berlebihan, mengkonsumsi lemak jenuh, penggunaan jelantah, kebiasaan konsumsi minuman beralkohol, obesitas, kurang aktivitas fisik, stres, dan penggunaan estrogen (Kemenkes RI, 2014).

Faktor-faktor yang mempengaruhi terjadinya penyakit hipertensi dibagi dalam dua kelompok besar yaitu faktor yang tidak dapat dimodifikasi/tidak dapat diubah seperti jenis kelamin, usia, genetik dan faktor yang dapat dimodifikasi/faktor yang dapat diubah seperti pola makan (junk food, asupan natrium, asupan lemak), kebiasaan olahraga dan lain-lain. Untuk terjadinya hipertensi perlu peran faktor risiko tersebut secara bersama-sama, dengan kata lain satu faktor risiko saja belum cukup menyebabkan timbulnya hipertensi. Hal ini antara lain dihubungkan dengan adanya gaya hidup masyarakat kota yang berhubungan dengan risiko hipertensi seperti stress, obesitas (kegemukan), kurangnya aktivitas fisik, merokok, alkohol, konsumsi kopi dan makan makanan yang tinggi kadar lemaknya.

Perubahan gaya hidup seperti perubahan pola makan menjurus ke sajian siap santap yang mengandung banyak lemak, protein, dan tinggi garam tetapi rendah serat pangan, membawa konsekuensi sebagai salah satu faktor berkembangnya penyakit degeneratif seperti hipertensi. (Djauhar Arif, dkk, 2013). Kecemasan juga merupakan satu-satunya faktor psikologis yang mempengaruhi hipertensi. Hal tersebut didukung pendapat dari Anwar (2012) pada banyak orang kecemasan atau stress psikososial dapat meningkatkan tekanan darah.

Studi pendahuluan yang dilakukan Peneliti dengan cara melakukan hasil survei awal pengukuran tekanan darah serta wawancara diperoleh hasil pemeriksaan tekanan darah dari 30 warga masyarakat dengan kriteria tidak menderita hipertensi sebanyak 3 orang dan yang menderita pre-hipertensi sebanyak 9 orang dan yang menderita hipertensi sebanyak 18 warga masyarakat. Beberapa pemicu yang menyebabkan penyakit hipertensi dapat dicegah sedini mungkin yaitu dengan mengetahui faktor-faktor risiko penyebab hipertensi.

Hipertensi pada dasarnya mengurangi harapan hidup para penderitanya. Penyakit ini menjadi muara beragam penyakit degeneratif yang bisa mengakibatkan kematian. Hipertensi selain mengakibatkan angka kematian yang tinggi juga berdampak kepada mahalnya pengobatan dan perawatan yang harus ditanggung para penderitanya. Perlu pula diingat hipertensi berdampak pula bagi penurunan kualitas hidup. Bila seseorang mengalami tekanan darah tinggi dan tidak mendapatkan pengobatan secara rutin dan pengontrolan secara teratur, maka hal ini akan membawa penderita ke dalam kasus-kasus serius bahkan kematian.

\section{METODE}

Pada penelitian ini dilakukan dengan desain penelitian observasional analitik. Metode penelitian dengan survey dan menggunakan pendekatan cross sectional yaitu rancangan penelitian dengan melakukan pengukuran atau pengamatan pada waktu observasi data dalam satu kali pada satu saat. Populasi dalam penelitian ini adalah semua penderita hipertensi yang ada di kelurahan Indrasari yang memenuhi kriteria sebanyak 87 orang. Variabel Independen pada penelitian ini yaitu riwayat keluarga dan aktivitas fisik dan variabel dependennya kejadian Hipertensi. Uji hipotesis yang digunakan adalah uji chi square untuk mengetahui Analisis Hubungan Riwayat Keluarga dan Aktivitas Fisik Dengan Kejadian Hipertensi.

\section{HASIL DAN PEMBAHASAN Analisis Univariat}

Tabel 1. Distribusi Frekuensi Berdasarkan Kejadian Hipertensi, Tingkat Pendidikan, Pengetahuan, Riwayat Keluarga, Aktifitas Fisik di Kelurahan Indrasari Kabupaten Banjar

\begin{tabular}{lcc}
\hline \multicolumn{1}{c}{ Variabel } & n & \% \\
\hline Kejadian Hipertensi & & \\
Hipertensi & 55 & 63,2 \\
Tidak Hipertensi & 32 & 36,8 \\
Tingkat Pendidikan & & \\
Tinggi & 36 & 41,4 \\
Rendah & 51 & 58,6 \\
Pengetahuan & & \\
Baik & 29 & 33,3 \\
Kurang & 58 & 66,7 \\
Riwayat Keluarga & & \\
Ada & 19 & 21,8 \\
Tidak Ada & 68 & 78,2 \\
Aktivitas Fisik & & \\
Tinggi & 54 & 62,1 \\
Rendah & 33 & 37,9 \\
\hline
\end{tabular}


Berdasarkan hasil penelitian di kelurahan Indrasari Kabupaten Banjar menunjukkan bahwa yang mengalami hipertensi sebanyak 55 responden $(63,2 \%)$, sedangkan yang tidak menderita hipertensi sebanyak 32 responden $(36,8 \%)$. Responden yang berpendidikan tinggi sebanyak 36 responden $(41,4 \%)$, sedangkan yang berpendidikan rendah sebanyak 51 responden $(58,6 \%)$. Responden yang berpengetahuan baik sebanyak 29 responden $(33,3 \%)$, sedangkan yang berpengetahuan kurang sebanyak 58 responden $(58,6 \%)$. Keluarga responden yang memiliki riwayat penyakit hipertensi sebanyak 19 responden (21,8\%), sedangkan keluarga responden yang tidak memiliki riwayat penyakit hipertensi sebanyak 68 responden $(78,2 \%)$. Responden yang aktivitas fisiknya tinggi sebanyak 54 responden $(62,1 \%)$, sedangkan yang aktivitas fisiknya rendah sebanyak 33 responden $(37,9 \%)$.

\section{Analisa Bivariat}

Tabel 2. Analisis Hubungan Status Riwayat Keluarga, Aktivitas Fisik dengan Kejadian Hipertensi di Kelurahan Indrasari Kabupaten Banjar

\begin{tabular}{|c|c|c|c|c|c|c|c|c|}
\hline \multirow{3}{*}{ Variabel } & \multicolumn{4}{|c|}{ Kejadian Hipertensi } & \multirow{2}{*}{\multicolumn{2}{|c|}{ Total }} & \multirow{3}{*}{ p-value } & \multirow[b]{3}{*}{ Nilai OR } \\
\hline & \multicolumn{2}{|c|}{ Hipertensi } & \multicolumn{2}{|c|}{ Tidak Hipertensi } & & & & \\
\hline & $\mathbf{n}$ & $\%$ & n & $\%$ & $\mathbf{n}$ & $\%$ & & \\
\hline \multicolumn{9}{|l|}{ Riwayat Keluarga } \\
\hline Ada & 11 & 37,9 & 18 & 62,1 & 29 & 100 & \multirow{2}{*}{0,001} & \multirow{2}{*}{0,194} \\
\hline Tidak Ada & 44 & 75,9 & 14 & 24,1 & 58 & 100 & & \\
\hline \multicolumn{9}{|l|}{ Aktivitas Fisik } \\
\hline Tinggi & 6 & 31,6 & 13 & 68,4 & 19 & 100 & \multirow{2}{*}{0,001} & \multirow{2}{*}{0,179} \\
\hline Rendah & 49 & 72,1 & 19 & 27,9 & 68 & 100 & & \\
\hline
\end{tabular}

Hasil uji statistik chi square diperoleh nilai $p=$ $0,001<\alpha 0,005$ berarti Ho ditolak. Dengan demikian dapat disimpulkan bahwa ada hubungan antara riwayat Keluarga dengan kejadian hipertensi. Hasil analisis didapatkan nilai Odds Ratio (OR) sebesar 0,179 artinya secara statistik risiko kejadian hipertensi dimana riwayat keluarga yang mempunyai hipertensi memberikan peluang kepada responden 1 kali lebih besar dibandingkan responden yang tidak memiliki riwayat keluarga dengan penyakit hipertensi.

Hasil uji statistik chi square diperoleh nilai $p=$ $0,001<\alpha 0,005$ berarti Ho ditolak. Dengan demikian dapat disimpulkan bahwa ada hubungan antara Aktivitas Fisik dengan kejadian hipertensi. Hasil analisis didapatkan nilai Odds Ratio (OR) sebesar 4,280 artinya secara statistik risiko kejadian penyakit hipertensi dimana responden yang mempunyai aktifitas fisik yang tinggi memberikan peluang responden terkena hipertensi 4 kali lebih besar dibandingkan responden yang melakukan aktivitas fisiknya rendah.

\section{Pembahasan}

\section{Analisis Hubungan Riwayat Keluarga dengan Kejadian Hipertensi di Kelurahan Indrasari Kabupaten Banjar}

Hasil uji statistik chi square diperoleh nilai $p=$ $0,001<\alpha 0,005$ berarti Ho ditolak. Dengan demikian dapat disimpulkan bahwa ada hubungan antara riwayat Keluarga dengan kejadian hipertensi. Hal ini sejalan dengan penelitian tentang analisis faktor risiko kejadian hipertensi pada masyarakat di pesisir sungai Siak Kecamatan Rumbai Kota Pekanbaru, menunjukkan bahwa mayoritas responden yang menderita penyakit hipertensi memiliki riwayat penyakit hipertensi keluarga sebanyak $71,8 \%$. Keluarga yang memiliki hipertensi dan penyakit jantung meningkatkan risiko hipertensi 2 sampai 5 kali lipat. Adanya faktor genetik yang ada pada keluarga dapat menyebabkan risiko untuk menderita penyakit hipertensi. Hal ini berhubungan erat dengan peningkatan kadar sodium intraseluler dan rendahnya rasio antara potasium terhadap sodium. Individu orang tua menderita hipertensi mempunyai risiko dua kali lebih besar untuk menderita hipertensi daripada orang yang tidak mempunyai keluarga dengan riwayat hipertensi. Selain itu didapatkan 70-80\% kasus hipertensi esensial dengan riwayat hipertensi dalam keluarga.

\section{Analisis Hubungan Aktivitas Fisik dengan Kejadian Hipertensi di Kelurahan Indrasari Kabupaten Banjar}

Hasil uji statistik chi square diperoleh nilai $p=$ $0,001<\alpha 0,005$ berarti Ho ditolak. Dengan demikian dapat disimpulkan bahwa ada hubungan antara Aktivitas Fisik dengan kejadian hipertensi. Hal ini sejalan dengan penelitian tentang faktor risiko kejadian hipertensi pada laki-laki di wilayah kerja Puskesmas TawangrejoKartoharjo Kota Madiun yang menunjukkan bahwa aktivitas fisik merupakan faktor risiko kejadian hipertensi. Aktivitas fisik yang mampu membakar kalori 800-1000 kalori akan meningkatkan high density lipoprotein (HDL) sebesar $4.4 \mathrm{mmHg}$. Sebagian besar studi epidemiologi dan studi intervensi aktivitas memberikan dukungan tegas bahwa peningkatan dari aktivitas fisik, durasi yang cukup, intensitas serta jenis sesuai, mampu menurunkan tekanan darah secara signifikan, baik dengan tersendiri maupun sebagai bagian dari upaya terapi pengobatan. Aktivitas fisik yang baik serta rutin akan melatih otot jantung dan tahanan perifer yang dapat mencegah peningkatan tekanan darah. 
Disamping itu pula, olahraga yang teratur dapat merangsang pelepasan hormon endorfin yang menimbulkan efek euphoria dan relaksasi otot sehingga tekanan darah tidak meningkat. Peningkatan intensitas aktivitas fisik, 30-45 menit per hari penting dilakukan sebagai strategi untuk pencegahan dan pengelolaan hipertensi.

\section{SIMPULAN}

Berdasarkan hasil penelitian yang dilakukan terhadap 87 responden tentang Analisis Hubungan Status Riwayat Keluarga, Aktivitas Fisik dengan Kejadian Hipertensi di Kelurahan Indrasari Kabupaten Banjar, yaitu yang mengalami hipertensi sebanyak 55 responden $(63,2 \%)$. Responden yang berpendidikan tinggi sebanyak 36 responden $(41,4 \%)$. Responden yang berpengetahuan baik sebanyak 29 responden $(33,3)$. Keluarga responden yang memiliki riwayat penyakit hipertensi sebanyak 19 responden $(21,8 \%)$. Responden yang aktivitas fisiknya tinggi sebanyak 54 responden $(62,1 \%)$. Ada hubungan antara riwayat keluarga, aktivitas fisik dengan kejadian hipertensi diperoleh nilai $p=0,001<\alpha 0,005$ dan diperoleh nilai $p=0,001<\alpha$ 0,005 .

\section{DAFTAR PUSTAKA}

Arif D. Faktor-faktor yang Berhubungan dengan Kejadian Hipertensi pada Lansia di Pusling Desa Klumpit UPT Puskesmas Gribig Kabupaten Kudus. 2013.

Anwar 2012. hubungan kecemasan dengan kejadian hipertensi: jogjakarta.(AHA) American Heart Association 2014. All About Heart Rate (Pulse). Available.

Bambang, Hartono. The Silent Killer. Jakarta: Perhimpunan Hipertensi Indonesia; 2011.

Departemen Kesehatan RI. (2006). Buku Pedoman Teknis Penemuan dan Tatalaksana Penyakit Hipertensi. Jakarta : 12-19.

Divine, Jon G. \& Rachma Apsari (eds),. (2012). Action Plan for High Blood Pressure. PT Intan Sejati. Klaten : 01-08.

Kementerian Kesehatan RI. (2013b). Hipertensi.Pusat Data dan Informasi Kementerian Kesehatan Republik Indonesia. Jakarta.

Kemenkes RI. Profil Kesehatan Indonesia. Jakarta: Kementrian Kesehatan Republik Indonesia, 2014.

Kokkinos PF ea. Physical Activity in The Prevention and Management of High Blood Pressure. Hellenic J Cardiology, vol: 50, hlm: 52-59. 2009.

Mannan H. Faktor Risiko Kejadian Hipertensi di Wilayah Kerja Puskesmas Bangkala Kabupaten Jeneponto. 2012.

Notoatmodjo S. Metodologi Penelitian Kesehatan. Jakarta: Rineka Cipta; 2010.
Pudiastuti, R.D. (2011). Penyakit Pemicu Stroke; Dilengkapi dengan Posyandu dan Posbindu PTM). Nuha Media. Yogyakarta: 01-39.

Rahajeng, E. \& Sulistyowati T. (2009). Prevalensi Hipertensi dan Determinannya di Indonesia. Majalah Kedokteran Indonesia, Vol. 59, No. 12.

Robbins. Buku Ajar Patologi, Edisi 7. Volume 2. Jakarta: Buku Kedokteran EGC; 2010.

Rohaendi. Treatment Of High Blood Pressure. Jakarta: Gramedia Pustaka Utama; 2008.

Sapitri N. Analisis Faktor Risiko Kejadian Hipertensi pada Masyarakat di Pesisir Sungai Siak Kecamatan Rumbai Kota Pekanbaru. Jim FK Volume 3 No1 Februari 2016. 2016.

WHO. World health day 2013: calls for Intensified efforts to prevent and control hypertension. 2013. 